\section{Kustamonu Eğitim Dergisi Kastamonu Education Journal}

Eylül 2019 Cilt:27 Sayı:5

kefdergi.kastamonu.edu.tr
Başvuru Tarihi/Received: 13.06.2018

Kabul Tarihi/Accepted: 17.01.2019

DOI: 10.24106/kefdergi.3154

\title{
Türkiye'deki Akademisyen Hemşirelerin Örgütsel Vatandaşlık Davranışlarının İncelenmesi
}

\section{Investigation of Academician Nurses Organizational Citizenship Behaviours in Turkey}

\section{Öz}

\author{
Fatma ORGUN ${ }^{1}$, Nilay ÖZKÜTÜK², Hale SEZER ${ }^{3}$
}

Örgütsel vatandaşık davranışı, çalışanların yardımlaşma eğilimini arttrarak örgüt içerisindeki bilgi paylaşımını geliştirmektedir. Bu davranış, örgütlerin başarısını arttırmaktadır. Türkiye'deki akademisyen hemşirelerin örgütsel vatandaşlık düzeylerinin incelenmesi amacıyla yapılan tanımlayıcı tipte bir araştırmadır. Örneklemi, Türkiye'deki Hemşirelik eğitimi veren yükseköğretim kurumlarında görev yapan ve araştırmaya katılmayı kabul eden akademisyen hemşireler ( $n=676$ ) oluşturmuştur. Veri toplama aracı olarak "Kişisel Bilgi Formu" ve Altuntaş ve Baykal (2010) tarafindan geçerlik ve güvenirliği yapılan Örgütsel Vatandaşlık Düzeyi Ölçeği kullanılmıştr. Akademisyen hemşirelerin örgütsel vatandaşlık düzeyi $X=3,45 \pm 1,54$ bulunmuştur. Akademisyen hemşirelerin eğitim durumlarının, toplam çalışma yıllarının, akademik kadrolarının ve kadro durumlarının örgütsel davranışlarını etkilediği saptanmıştır. Bu bağlamda örgüt liderlerinin kurum içerisinde örgütsel davranış düzeylerini arttırmaya yönelik düzenlemeler yapması önerilmektedir.

\section{Anahtar Kelimeler: örgütsel vatandaşlık düzeyi, hemşire, akademisyen}

\section{Abstract}

Organizational citizenship behavior improves the sharing of information within the organization by increasing the tendency of employees to cooperate. This behavior increases the success of organizations. Academician nurses who are working at nursing education institutions in Turkey is a descriptive study in order to examine level of organizational citizenship. Sampling, working in higher nursing education institutions in Turkey who agreed to participate in the research scholars of the nurses $(n=676)$ were formed. Data collection forms were Individual Identification Form and Organizational Citizenship Level Scale which was made reliability and validity by Altuntaş and Baykal (2010). According to findings, academician nurses' level of organizational citizenship $(X=3.45 \pm 1,54)$ were found. Academician nurses' education status, total working years, academic staff and cadre statuses were found to affect organizational behavior. In this context, it is proposed that organizational leaders should make arrangements to increase the level of organizational behavior within the organization.

Keywords: organizational citizenship level, nurse, academician 


\section{Extended Abstract}

Aim: The realization of the goals of individuals and organizations in organizational life is one of the basic goals for managers. While reaching its goals, it is the basic necessity of the organization's life to reach the aims of the individuals, to reach the aims of the individuals while reaching their own purposes. In this context, organizational citizenship behavior is a balancing factor in achieving individual and organizational goals. The development of a society and the pace of the developing age are the responsibility of the people living in that society, and the development of an organization is the responsibility of the people living in that organization. Organizational citizenship behavior by Smith, Organ, and Near (1983) has been described as behavior aimed at helping other people within the organization, as demonstrated by their willingness beyond the official role within the organization. It is important for managers academicians nurses to have a vision of organizational citizenship behavior that employees show in the workplace so that training services can be presented more efficiently and executive academics nurses can increase employee satisfaction, job satisfaction, performance and organizational commitment. So that, Academician nurses who are working at nursing education institutions in Turkey is a descriptive study in order to examine level of organizational citizenship.

Method: Academician nurses in nursing education institutions in Turkey planned in order to examine the level of organizational citizenship and was descriptive model research. The study sample was School of Nursing $(n=6)$, School of Health $(n=54)$, the Faculty of Health Sciences $(n=25)$, the School of Health Sciences $(n=3)$ and the Faculty of Nursing $(n=5)$ total 95 institution in Turkey which Faculty nurses are working and who agreed to participate in the study $(n=676)$ were included. Data collection forms were Individual Identification Form and Organizational Citizenship level Scale which was made reliability and validity by Altuntaş and Baykal (2010). Data were collected by researchers from research institutions for necessary written permission has been obtained.

Results : It was found that $31.7 \%$ of the academicians nurses were research assistants ( $n=214), 15.7 \%$ were Internal Diseases Nursing $(n=106), 15.7 \%$ were Women Health and Disease Nursing $(n=106)$ took place in the branches of the department, $45,1 \%$ had $33 /$ a permanent $(n=305)$ staff, $55,2 \%$ worked in the same institution for $0-5$ years $(n=373), 35.2 \%$ of them were working for $11-20$ years $(n=238)$. According to findings, Academician nurses' level of organizational citizenship $(X=3.45 \pm 1,54)$ were found to moderate. When the educational status of academic nurses and Organizational Citizenship level Scale are compared, a statistically significant difference was found $(p<0,05)$. As a result of the further analysis of the constructed Tukey HSD, it was determined that the difference was derived from doctoral education. A statistically significant difference was found between the academic title of the academic nurses participating in the study and the organizational citizenship level $(p<0,05)$. As a result of further analysis, it was determined that this difference was due to lecturer and the associate professors. A statistically significant difference was found when the total working years of the academic nurses were compared with the Organizational Citizenship Scale. As a result of the further analysis of the constructed Tukey HSD, it was found that the difference in the tolerance dimension of the organizational citizenship scale of the academical nurses was in favor of those with a total working year of 21 years and over.

Conclusion: As a result of this study, academician nurses who are working in nursing education institution in Turkey, organizational citizenship level was determined. The level of organizational citizenship was found to be moderate. Educational status, academic title, and overall working years have been identified as important variables affecting organizational citizenship behavior. The academicians' managers determine the level of organizational citizenship of academicians nurses in their institutions and feel that they support and reward nurse academicians who exhibit these behaviors, It is recommended that academics managers determine the level of organizational citizenship of nursing academics in their institutions and support and reward nurses academicians who exhibit these behaviors and feel that they are more important. 


\section{Giriş}

Değişen, sürekli gelişen teknolojiler ve yönetim sistemleri örgütlerin gelişmesi için bir firsat yaratsa da, örgütlerin başarısını artttracak ya da azaltacak en önemli kaynak işgörenlerdir (Sezgin, 2005; Pohlman ve Gardiner, 2000). Çünkü bu sistemleri ve teknolojik araç-gereç kaynaklarını işgörenler kullanmaktadır. Bu nedenle, işgörenlerin kurum içerisindeki tutum ve davranışları örgütlerin verimliliğini etkilemektedir (Sezgin, 2005; Acquaah, 2004; Wagner ve Rush, 2000; Somech ve Drach-Zahavy, 2004).

1980 lerden itibaren, gerek akademik çevrelerde gerekse iş dünyasında işgörenler üzerine çalışmalar yapılmaya başlanmıştır (Bolat ve ark, 2009; Çalık ve ark, 2009). Örgüt içinde işgörenlerin girişimcilik ve yaratıcılık becerilerini arttırmaya yönelik yapılan çalışmalar sonucunda, "paylaşma, yardım etme, destekleme ve koruyup bakım verme gibi diğerinin yararını ya da yardımı amaçlayan gönüllü bir davranış olarak tanımlanan prososyal davranış biçimi olan örgütsel vatandaşlık davranışı (ÖVD)" tanımlanmıştır (Bolat ve ark, 2009; Çalık ve ark, 2009). ÖVD, formal iş tanımlarının ötesinde, "belirlenmiş rol gereklerini ve beklentilerini aşan, işgörenlerin örgüte katkıda bulunmak için istekli olarak gösterdikleri rol fazlası davranışları" ifade etmektedir (McDonald, 1993; Schnake ve Dumler, 2003; Feather ve Rauter, 2004). Bir başka deyişle, ÖVD, "bireyin örgüt içerisindeki resmi rolünün ötesinde kendi isteğine bağlı olarak gösterdiği ve örgüt içerisindeki diğer insanlara yardım etmeyi amaçlayan davranışlar" olarak tanımlanmıştır (Smith ve ark, 1983; Titrek ve ark, 2009).

Gönüllü bir davranış olan, herhangi formal görev tanımında yer almayan bu davranış olmadan örgütlerin ayakta kalabilmesi ve gelişimine devam etmesi mümkün değildir. Bu bağlamda, formal iş ve görev tanımlarının dışında sorumluluk üstlenen ve özveride bulunan, örgütsel etkililiğe ve gelişmeye katkıda bulunmaya çaba sarf eden çalışanlara ihtiyaç vardır (Somech ve Drach-Zahavy, 2004; Wagner ve Rush, 2000; Önder ve Taş, 2012).

ÖVD sadece iş hayatında değil yükseköğretim kurumlarında da araştırılmaya başlanmıştır. Yükseköğretim kurumlarındaki eğitim hizmetleri, uluslararası alanda gelişen ve değişen teknolojilerden, bilimsel bilgilerden ve yönetim sistemlerinden etkilenmektedir. Değişimler, yükseköğretim sektörünü, yükseköğretim hizmetlerini radikal bir şekilde değiştirmektedir (Aktan, 2009). Akademisyen hemşirelerin, çalıştı̆ı kurumda huzurlu ve verimli çalışabilmeleri, kurumun başarısı açısından son derece önemlidir. Bunun önemi, yarının nitelikli insan gücünü yetiştiren kurumlar olmalarıdır. Akademisyen hemşirelerin işe ve kuruma yönelik olumlu tutumlar geliştirmelerinde, yöneticilerin duyarlılık göstermesi, bu tutum boyutlarını etkileyen faktörlerin kurumsal açıdan dikkate alınması ve olumlu tutum geliştirilmesine yönelik düzenlemelerin yapılması gerekmektedir (Yıldııım ve Çam, 2011). Bununla birlikte, yükseköğretimde eğitim hizmetlerinin daha verimli bir şekilde sunulabilmesi için, yönetici akademisyen hemşirelerin çalışanlarının örgütsel vatandaşlık davranışı hakkında öngörü geliştirmeleri önem kazanmaktadır (Altuntaş ve Baykal, 2010).

ÖVD'nin işin yapılması için gerekli olmamasına karşın çalışanlar arasındaki ilişkilerin geliştirilmesinde ve kurumsal gelişimin sağlanmasındaki önemi gün geçtikçe daha da vurgulanmaktadır. Geleceğin meslek üyelerinin ve bilim insanlarının yetiştirildiği yükseköğretim kurumlarında da ÖVD’nin sergilenmesi ile yaşanan örgütsel gelişim ve değişim bu kurumların verdiği hizmetin çıktılarına yani öğrencilere de olumlu yönde yansıyacaktır. Ayrıca, hemşirelik eğitimi veren yükseköğretim kurumlarında görev yapan akademisyenlerin gösterdikleri ÖVD düzeyi ve bunu etkileyen faktörlerin bilinmesi, örgütün geliştirilmesi adına girişimlerde bulunacak yöneticiler açısından oldukça önemli bir veri kaynağı olarak değerlendirilebilir (Baykal ve ark, 2011).

Bu bağlamda, Türkiye'de yükseköğretimde görev alan akademisyen hemşirelerin görev ve iş tanımlarında yer almayan kurumun gelişmesine öncülük edebilecek çalışan davranışlarının belirlenmesi kurum hizmetlerinin geliştirilmesi açısından önemlidir.

\section{Yöntem}

\section{Araştırmanın Amacı}

Bu araştırma, Türkiye'de hemşirelik eğitimi veren kurumlarda görev yapan akademisyen hemşirelerin örgütsel vatandaşıı düzeylerinin incelenmesi amacıyla tanımlayıcı tipte yapılan bir araştırmadır ve Türkiye'deki tüm akademisyen hemşireleri kapsaması açısından da alana değerli bir veri sağlamaktadır.

Araştrrma soruları;

1.Örgütsel vatandaşlık davranışına ilişkin akademisyen hemşirelerin “ÖVD” ne düzeydedir?”

2.Akademisyen hemşirelerin ÖVD düzeyleri bazı sosyo-demografik değişkenlere" göre farklılık göstermekte midir? 
Araştırma kapsamına Ocak 2012- Haziran 2015 tarihleri arasında Türkiye'deki Hemşirelik Yüksekokullarında ( $n=6$ ), Sağlık Yüksekokullarında ( $n=54)$, Sağ ık Bilimleri Fakültelerinde $(n=25)$, Sağlık Bilimleri Yüksekokullarında $(n=3)$, Hemşirelik Fakültelerinde $(n=5)$ toplam 95 kurumda görev yapan ve araştrmaya katılmayı gönüllü olarak kabul eden akademisyen hemşireler ( $n=1245$ ) alınmıştr. Örnekleme alınan 95 hemşirelik okulundan 11'i çalışma için uygulama izni vermemiş, 25'i uygulama izni alınmasına rağmen gönderilen anket formlarını geriye göndermemiştir. Veriler, anket formlarına yanıt veren 59 hemşirelik okulundan ( $n=768)$ toplanmıştı. Araştırmada 1245 akademisyen hemşireye ulaşılması hedeflenmiş ancak 676 akademisyen hemşire çalışmaya katılmış ve Türkiye'de bulunan akademisyen hemşirelerin \%54.3'üne ulaşılımıştr. Araştırma için Ege Üniversitesi Hemşirelik Fakültesi Etik Kurul'undan onay (23/05/2014 tarihli 2014-65 sayılı) ve örnekleme alınan 84 kurumdan uygulama izni alınmıştır.

Veri toplama aracı olarak hemşire akademisyenlerin sosyo-demografik özelliklerini içeren ve araştrmacılar tarafindan hazırlanan "Kişisel Bilgi Formu" ve Altuntaş ve Baykal (2010) tarafindan geçerlik ve güvenirliği yapılan Örgütsel Vatandaşlık Düzeyi Ölçeği kullanılmıştır.

Kişisel Bilgi Formu: Akademisyen Hemşirelerin yaş, cinsiyet, medeni durum, eğitim durumu, ünvan, kurum ve toplam çalışma yılı, bölüm, idari görev, kadro tipini belirlemeye yönelik kişisel özelliklerini içeren 10 soru ve ÖVD tanımı ve algılarına ilişkin 2 soru yer almaktadır.

Örgütsel Vatandaşıık Düzeyi Ölçeği (ÖVDö): Çalışanların ne sıklıkta örgütsel vatandaşlık davranışı sergilediklerini belirleyen ÖVDÖ, Dolma (2003) tarafindan geliştirilmiş ve Altuntaş ve Baykal (2010) tarafindan hemşirelik alanında çalışan hemşireler üzerinde geçerlik ve güvenirlik çalışması yapılmıştır. Dolma (2003) tarafindan geliştirilen orijinal ölçek; yardım etme, vicdanlıık, hoşgörülülük, bilgilendirme, katılım ve kurumu övme olarak 6 faktör grubuna ayrılmakla birlikte Altuntaş ve Baykal (2010) tarafindan yapılan çalışmada; 5 faktör grubuna ayrılmış ve orjinal ölçekte yer alan katılım alt boyutu ile ilgili maddelerin bilgilendirme alt boyutu içinde yer aldığı görülmüştür. Altuntaş ve Baykal (2010) tarafindan yapılan ÖVDÖ'nin iç tutarlılık incelemesi sonucunda ölçeğin toplam Cronbach alfa değerinin $r=.87$, alt boyut Cronbach alfa değerlerinin Vicdanlıık alt boyutunda $r=.77$, Kurumu Övme alt boyutunda $r=.74$, Bilgilendirme-Katılım alt boyutunda $r=.68$, Hoşgörülülük alt boyutunda $r=.76$ ve Yardım Etme alt boyutunda $r=.68$ olduğu ve ÖVDÖ’nin yüksek derecede güvenilir olduğu belirlenmiştir.

Ölçeğe ilişkin tarafimızdan yapılan güvenirlik analizi sonucu bulunan güvenirlik katsayısı ise $r=.90$ dir. Alt boyutlara bakıldığında; Vicdanlılık r=.95, Kurumu Övme $r=.89$, Bilgilendirme-Katılım $r=.96$, Hoşgörülülük $r=.77$ ve Yardım Etme $r=.95$ olduğu bulunmuştur. ÖVDÖ'i 24 maddeden oluşmakta ve 7'li cevap seçenekleri (her zaman-7, çoğu zaman-6, yarıdan fazla-5, yarı yarıya-4, yarıdan az-3, nadiren-2, hiçbir zaman-1) bulunmaktadır. Ölçek, 1 ile 7 arasında puanlandırılmaktadır. Ölçek toplamı ve alt boyutlardan alınan ortalama puan $(3,5)$ üzerine çıktıkça örgütsel vatandaşlık düzeyinin arttğı şeklinde değerlendirilmektedir.

\section{Bulgular}

Araştırma kapsamına alınan akademisyen hemşirelerin sosyo-demografik verileri incelendiğinde; akademisyen hemşirelerin \%41.3'ünün 31-40 yaş, \%98.8'inin kadın, \%57.1'inin evli, \%54.3'ünün doktora mezunu, \%22.9'unun Doktor Öğretim Üyesi, \%31.7'sinin Araştrrma Görevlisi oldukları, \%77.2'sinin herhangi bir idari kadroda görevli olmadığı, \%45.1'inin 33/a daimi kadroda olduğu belirlenmiştir. Akademisyen hemşirelerin \%55.2'sinin 0-5 yıldır aynı kurumda çalıştı̆ı, \%43.3'ünün örgütsel vatandaşlık kavramını bildiği ve \%52.4'ünün de kendi örgütsel vatandaşlık düzeyini "iyi" olarak algıladıklarını ifade ettikleri belirlenmiştir.

Tablo 1. Örgütsel Vatandaşlık Düzeyi (ÖVD) Ölçeği Puan Ortalamaları (N=676)

\begin{tabular}{lcccc}
\hline ÖVD Ölçeği & $X$ & Ss & Min & Max \\
\hline Toplam & 3.45 & 1.54 & 1.25 & 6.58 \\
Vicdanlılık & 3.20 & 2.24 & 1.00 & 7.00 \\
Kurumu Övme & 3.51 & 1.68 & 1.00 & 7.00 \\
Bilgilendirme / Katılım & 3.28 & 2.00 & 1.00 & 7.00 \\
Hoşgörülülük & 4.01 & 1.19 & 1.25 & 7.00 \\
Yardım Etme & 3.46 & 1.77 & 1.00 & 7.00 \\
\hline
\end{tabular}

Akademisyen hemşirelerin ÖVD Ölçeği'nin ve alt boyutlarının puan ortalamalarının ölçek toplamında $X=3.45 \pm 1.54$, vicdanlııık $X=3.20 \pm 2.24$, kurumu övme $X=3.51 \pm 1.68$, bilgilendirme/katılım $X=3.28 \pm 2.00$, hoşgörülülük $X=4.01 \pm 1.19$ ve yardım etme alt boyutlarında $X=3.46 \pm 1.77$ olduğu saptanmıştı (Tablo 1 ). 
Tablo 2. Akademisyen Hemşirelerin Eğitim Durumları, Çalışma Yılları, Akademik Kadroları ve Kadro Durumları ile ÖVD Ölçeği Puan Ortalamalarının Karşılaştırılması

\begin{tabular}{|c|c|c|c|c|c|c|c|c|c|c|c|c|c|}
\hline & & \multicolumn{12}{|c|}{ Örgütsel Vatandaşlık Düzeyi Ölçeği (ÖVDÖ) } \\
\hline & & \multicolumn{2}{|c|}{ Toplam } & \multicolumn{2}{|c|}{ Vicdanlılık } & \multicolumn{2}{|c|}{ Kurumu Övme } & \multicolumn{2}{|c|}{$\begin{array}{l}\text { Bilgilendirme / } \\
\text { Katılım }\end{array}$} & \multicolumn{2}{|c|}{ Hoşgörülülük } & \multicolumn{2}{|c|}{ Yardım Etme } \\
\hline & & $x$ & Ss & $\mathrm{x}$ & Ss & $x$ & Ss & $\mathrm{x}$ & Ss & $x$ & Ss & $\mathrm{x}$ & Ss \\
\hline \multirow{4}{*}{ 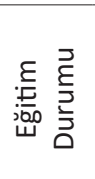 } & Lisans (53) & 3.10 & 1.33 & 2.71 & 1.90 & 3.22 & 1.61 & 2.80 & 1.63 & 3.98 & 1.17 & 3.19 & 1.64 \\
\hline & Yüksek Lisans (256) & 3.28 & 1.40 & 2.94 & 2.06 & 3.36 & 1.54 & 3.09 & 1.76 & 3.98 & 1.18 & 3.31 & 1.62 \\
\hline & Doktora (367) & 3.61 & 1.64 & 3.46 & 2.37 & 3.66 & 1.78 & 3.49 & 2.18 & 4.03 & 1.20 & 3.60 & 1.87 \\
\hline & & \multicolumn{2}{|c|}{ F:5.163 p: .006* } & \multicolumn{2}{|c|}{ F:5.521 p:.004* } & \multicolumn{2}{|c|}{$\mathrm{F}: 3.29$ p: .038* } & \multicolumn{2}{|c|}{ F:4.731 p:.009* } & \multicolumn{2}{|c|}{$\mathrm{F}: .112 \mathrm{p}: .894$} & \multicolumn{2}{|c|}{$F: 2.688 p: .069$} \\
\hline \multirow{6}{*}{ 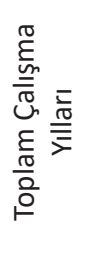 } & $0-5$ yıl (178) & 3.44 & 1.42 & 3.21 & 2.12 & 3.55 & 1.54 & 3.25 & 1.67 & 3.85 & 1.17 & 3.54 & 1.70 \\
\hline & 6-10 yıl (127) & 3.42 & 1.52 & 3.11 & 2.19 & 3.57 & 1.67 & 3.35 & 1.98 & 3.98 & 1.16 & 3.36 & 1.77 \\
\hline & $11-20$ yıl (238) & 3.44 & 1.56 & 3.22 & 2.27 & 3.51 & 1.67 & 3.27 & 2.11 & 4.01 & 1.21 & 3.41 & 1.74 \\
\hline & $21-\uparrow(133)$ & 3.49 & 1.69 & 3.26 & 2.40 & 3.40 & 1.91 & 3.27 & 2.24 & 4.23 & 1.19 & 3.51 & 1.91 \\
\hline & & $F: .045$ & p:.987 & \multicolumn{2}{|c|}{ F:.110p:.954 } & \multicolumn{2}{|c|}{ F:.272 p:.845 } & \multicolumn{2}{|c|}{ F:.062 p:.980 } & \multicolumn{2}{|c|}{ F:2.630p:.049* } & $F: .329$ & $\mathrm{p}: .805$ \\
\hline & Profesör (18) & 3.72 & 1.86 & 3.59 & 2.65 & 3.69 & 2.11 & 3.58 & 2.56 & 4.32 & 1.37 & 3.57 & 2.14 \\
\hline \multirow{7}{*}{ 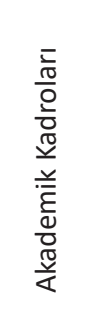 } & Doçent (58) & 3.71 & 1.80 & 3.65 & 2.56 & 3.66 & 1.98 & 3.48 & 2.36 & 4.09 & 1.19 & 3.78 & 1.98 \\
\hline & Dr. Öğr. Üyesi (155) & 3.35 & 1.61 & 3.05 & 2.27 & 3.46 & 1.82 & 3.16 & 2.20 & 4.11 & 1.19 & 3.25 & 1.78 \\
\hline & Öğretim Gör. Dr. (40) & 3.26 & 1.48 & 2.94 & 2.17 & 3.45 & 1.40 & 3.09 & 1.97 & 3.93 & 1.15 & 3.19 & 1.71 \\
\hline & Öğretim Görevlisi (152) & 3.01 & 1.31 & 2.55 & 1.83 & 3.13 & 1.59 & 2.73 & 1.70 & 3.99 & 1.23 & 3.07 & 1.60 \\
\hline & Araştırma Gör. Dr. (32) & 3.72 & 1.58 & 3.71 & 2.43 & 3.79 & 1.58 & 3.78 & 2.04 & 3.75 & 1.19 & 3.56 & 1.80 \\
\hline & Araştirma Gör. (214) & 3.75 & 1.48 & 3.64 & 2.24 & 3.78 & 1.54 & 3.68 & 1.82 & 3.91 & 1.16 & 3.85 & 1.72 \\
\hline & Okutman (7) & 2.52 & .46 & 1.86 & .86 & 1.82 & .49 & 2.20 & 1.47 & 4.86 & .76 & 2.43 & 1.26 \\
\hline \multirow{8}{*}{$\begin{array}{l}\frac{\bar{L}}{\frac{10}{E}} \\
\frac{E}{3} \\
\frac{1}{3} \\
0 \\
0 \\
\frac{0}{0} \\
\frac{\pi}{2}\end{array}$} & & \multicolumn{2}{|c|}{$\mathrm{F}: 4.047 \mathrm{p}: .000^{*}$} & \multicolumn{2}{|c|}{$\mathrm{F}: 4.369 \mathrm{p}: .000^{*}$} & \multicolumn{2}{|c|}{ F:3.168 p:.003* } & \multicolumn{2}{|c|}{$F: 3.757$ p:.001* } & $F: 1.345$ & $\mathrm{p}: 226$ & $F: 3.705$ & p:.001* \\
\hline & Yüksek Lisans tah. (94) & 3.13 & 1.39 & 2.71 & 1.96 & 3.21 & 1.61 & 2.81 & 1.68 & 4.14 & 1.14 & 3.14 & 1,65 \\
\hline & Doktora tah. (103) & 3.18 & 1.57 & 2.86 & 2.21 & 3.28 & 1.77 & 2.94 & 2.21 & 4.06 & 1.14 & 3.08 & 1.78 \\
\hline & 33/a dai. (305) & 3.36 & 1.55 & 3.07 & 2.21 & 3.46 & 1.74 & 3.19 & 2.04 & 3.98 & 1.22 & 3.40 & 1.80 \\
\hline & $50 / d$ tah. $(41)$ & 4.45 & 1.51 & 4.62 & 2.25 & 4.48 & 1.61 & 4.49 & 1.88 & 4.04 & 1.03 & 4.45 & 1.57 \\
\hline & 35. madde (41) & 4.11 & 1.48 & 4.15 & 2.38 & 4.09 & 1.63 & 4.20 & 1.85 & 3.96 & 1.16 & 4.10 & 1.66 \\
\hline & ÖYP (92) & 3.60 & 1.40 & 3.48 & 2.22 & 3.56 & 1.32 & 3.50 & 1.72 & 3.92 & 1.29 & 3.67 & 1.68 \\
\hline & & \multicolumn{2}{|c|}{$\mathrm{F}: 7.078$ p:.000* } & \multicolumn{2}{|c|}{$\mathrm{F}: 6.936$ p:.000* } & $F: 4.93$ & p:..000* & \multicolumn{2}{|c|}{ F:7.000 p:.000* } & $\mathrm{F}: 448$ & p:.815 & F:5.767 & p:.000* \\
\hline
\end{tabular}

Akademisyen hemşirelerin eğitim durumları ile ÖVDÖ puan ortalamaları karşılaştırıldığında, ölçek toplamında ( $F=5.163 ; p=0.006)$, vicdanlılık ( $F=5.521 ; p=0.004)$, kurumu övme ( $F=3.294 ; p=0.038)$, bilgilendirme/katilım ( $F=4.731$; $p=0.009$ ) alt boyutları arasında istatistiksel olarak anlamlı bir fark bulunmuştur ( $p<0.05)($ Tablo 2). Yapılan Tukey HSD ileri analizi sonucunda, ölçek toplamı, vicdanlılık ve bilgilendirme/katılım alt boyutlarında farkın doktora eğitiminden kaynaklandığı belirlenmiştir $(p<0.05)$.

Akademisyen hemşirelerin akademik kadroları ile ÖVDÖ puan ortalamaları karşılaştıııldığında, ölçek toplamında $(F=4.047 ; p=0.000)$, vicdanlılık ( $F=4.369 ; p=0.000)$, kurumu övme $(F=3.168 ; p=0.003)$, bilgilendirme/katlım ( $F=3.757$; $p=0.001)$, yardım etme $(F=3.705 ; p=0.001)$ alt boyutları arasında istatistiksel olarak anlamlı bir fark bulunmuştur $(p<0.05)$ (Tablo 2). Yapılan Tukey HSD ileri analizi sonucunda farkın öğretim görevlisi ve doçentlik kadro durumundan kaynaklandığı belirlenmiştir $(p<0.05)$.

Akademisyen hemşirelerin kadro durumları ile ÖVDÖ puan ortalamaları karşılaştııllığında ölçek toplamında $(F=7.078 ; p=0.000)$, vicdanlılık ( $F=6.936 ; p=0.000)$, kurumu övme $(F=4.930 ; p=0.000)$, bilgilendirme/katlım ( $F=7.000$; $\mathrm{p}=0.000)$, yardım etme ( $\mathrm{F}=5.767 ; \mathrm{p}=0.000)$ alt boyutları arasında istatistiksel olarak anlamlı bir fark bulunurken $(\mathrm{p}<0.05)$; hoşgörülülük alt boyutu ile arasında istatistiksel olarak anlamlı bir fark bulunamamıştı ( $p>0.05$ ) (Tablo 2). Yapılan Tukey HSD ileri analizi sonucunda farkın ölçek toplamında, vicdanlıık, kurumu övme, bilgilendirme/katılım ve yardım etme alt boyutlarında farkın 50/d tahsisli kadro durumundan kaynaklandığı belirlenmiştir( $\mathrm{p}<0.05)$.

Akademisyen hemşirelerin toplam çalışma yılları ile ÖVDÖ puan ortalamaları karşılaştırıldığında toplam çalışma yılı ile sadece hoşgörülülük ( $F=2.630 ; p=0.049)$ alt boyutu arasında istatistiksel olarak anlamlı bir fark bulunmuştur $(p<0.05)$ (Tablo 2). Yapılan Tukey HSD ileri analizi sonucunda bu farkın toplam çalışma yılı 21 yıl ve üzeri olan hemşire akademisyenlerden kaynaklandığı belirlenmiştir $(p<0.05)$.

\section{Tartışma}

Bu çalışmada, örgütsel vatandaşlık davranışına ilişkin akademisyen hemşirelerin "ÖVD” ne düzeydedir?", "ÖVD düzeyleri bazı sosyo-demografik değişkenlere" göre farklılık göstermekte midir?" sorularına yanıt aranmıştır. 
Araştırma kapsamına alınan akademisyen hemşirelerin sosyo-demografik verileri ile alan yazındaki Baykal ve ark. (2011)'larının akademisyen hemşireler üzerinde yapmış oldukları çalışma bulguları benzerlik göstermektedir.

Çalışma kapsamına alınan akademisyen hemşirelerin \%31.7'sinin Araştırma Görevlisi kadrosunda oldukları, \%15.7'sinin iç Hastalıkları Hemşireliği, \%15.7'sinin Kadın Sağlı̆ı ve Hastalıkları Hemşireliği anabilim dallarında yer aldığı, \%45.1'inin 33/a daimi kadroya sahip olduğu, \%55.2'sinin 0-5 yıldır aynı kurumda çalıştı̆ı, \%35.2'sinin 11-20 yıldır çalışmakta olduğu belirlenmiştir. Alan yazın incelendiğinde; Baykal ve ark. (2011) akademisyen hemşireler üzerinde yapmış oldukları çalışmalarında, çalışmaya katılanların \%50.6'sının öğretim görevlisi/okutman kadrosunda görev yaptığını, \%26.6'sının Halk Sağlığı Hemşireliği veya Doğum ve Kadın Hastalıkları Hemşireliği anabilim dallarında görev yaptığını, \%64.1'inin 5 yıldan az mesleki deneyime ve \%41.8'inin de 6-10 yıl arasında kurumsal deneyime sahip olduğunu belirlemişlerdir. Bu bulgular, çalışma bulguları ile paralellik göstermektedir.

ÖVDÖ puan ortalamalarına bakıldığında akademisyen hemşirelerin toplam ölçek ve alt boyut puan ortalamalarının ortalama değerinin üzerinde olduğu ve en yüksek puan ortalamasının hoşgörülük alt boyutunda olduğu saptanmıştı (Tablo 1). Alan yazındaki akademisyen hemşireler üzerinde yapılmış olan çalışma sonuçları çalışma bulgularını destekler niteliktedir (Alim ve El-Rayed, 2017; Dirican ve Erdil, 2016; Baykal ve ark.,2011). Ayrıca Baykal ve ark. (2011)'larının akademisyen hemşireler üzerinde yapmış oldukları çalışmada, ÖVD ölçeğinden alınması gereken ortalama puanın üstünde bir

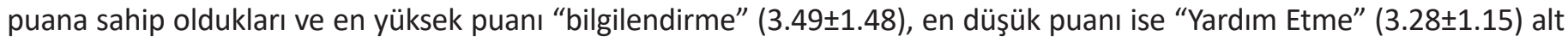
boyutundan aldıkları belirlenmiştir. Çalışmamızda ise, akademisyen hemşireler bilgilendirme/katılım alt boyutundan en düşük (3.28), hoşgörülülük alt boyutundan ise en yüksek puanı (4.01) almıştır. Bu çalışma, çalışma bulguları ile paralellik göstermemektedir.

İşsever ve ark. (2016)'ları çalışmalarında hemşirelerin ÖVD toplam puan ortalamalarını 3.78 \pm 0.61 ve Öz ve Özyürek (2018) ise 3.45 \pm 0.58 olarak bulmuşlardır. Bunun aksine Özkütük ve ark. (2012)'larının hemşireler üzerinde yapmış oldukları çalışma da hemşirelerin ÖVD toplam ortalama puanlarının (5.48) oldukça yüksek düzeyde olduğu ve hemşireler tarafindan en yüksek düzeyde algılanan alt boyutun ise "Yardım etme" alt boyutu olduğu bulunmuştur. Öztürk ve Özata (2013)'nın çalışmasında hemşirelerin "Özgecilik" alt boyutundan en yüksek (ort:4.27 ss:0.535), "Vatandaşılık Erdemi" alt boyutundan ise (ort:3.73 ss:0.825) en düşük ortalama değeri aldığı belirlenmiştir. Genel ÖVD ortalamalarının 4.05 olduğu tespit edilmiştir. Feather ve Rauter (2004) tarafindan kadrolu ve sözleşmeli öğretmenler arasında yapılan çalışmada öğretmenlerin örgütsel vatandaşık davranışları orta düzeyde bulunmuştur. Çalışma bulgularımızla kısmen paralellik gösteren bu çalışmalar doğrultusunda, çalışanların iş tanımlarında yer almayan ve yerine getirilmesi bireylerin kararına bırakılmış olan örgütsel vatandaşlık davranışını sergileme eğiliminde oldukları söylenebilir.

Çalışmaya katılan akademisyen hemşirelerin eğitim durumları ile ÖVDÖ puan ortalamaları arasında anlamlı bir fark bulunmuştur (Tablo 2). Bu farkın akademisyen hemşirelerin doktora eğitimi lehine olduğu saptanmıştır. Doktora eğitiminin örgütsel vatandaşlık düzeyini arttırdığı, lisans ve yüksek lisans yapmış olduğunu belirten akademisyen hemşirelere göre bu düzeyin daha yüksek olduğu söylenebilir. Çalışanın eğitim düzeyi arttıkça, örgütün gerçekleştirebileceğinden veya karşılayabileceğinden daha fazla beklentileri ortaya çıkmaktadır. Aynı zamanda alternatif iş imkânları da eğitim düzeyinin artmasına paralel olarak artş̧ göstermektedir. Bu durum, eğitim düzeyi arttıkça örgütsel bağlıık düzeyinin azaldığını göstermektedir. Ancak bununla birlikte, bireyin çalıştı̆ı örgütten aldığı eğitimler çalışanın üyesi olduğu örgüte karşı kendisini borçlu hissetmesine ve örgüte minnet duyduğu için çalışmaya devam etmesine sebep olmaktadır. Bu sebebin, örgütsel vatandaşlık davranışını arttırma yönünde etkisi olabileceği söylenebilir (Doğrul, 2013). Pirecioğlu (2010) tarafindan yapılan çalışmada örgütsel vatandaşlık davranışının boyutları ve eğitim arasındaki ilişki incelendiğinde, nezaket, sivil erdem ve genel örgütsel vatandaşlık davranışı açısından anlamlı fark bulunmuştur. Sivil erdem ve nezaket boyutlarını, yüksek lisans veya doktora eğitimine sahip olanların Sağılık Meslek Lisesi ve Ön lisans mezunlarına göre daha fazla sergilediği görülmüştür. Bunun nedenleri arasında yüksekokul bitiren bir hemşirenin iş tatmininin daha yüksek, bilimsel çalışmalara daha hevesli olması gösterilmiştir.

Çalışmaya katılan akademisyen hemşirelerin akademik kadroları ile örgütsel vatandaşık düzeyleri puan ortalamaları arasında anlamlı bir fark bulunmuştur (Tablo 2). Bu farkın kurumu övme, bilgilendirme/katılım ve yardım etme alt boyutlarında öğretim görevlisi ve vicdanlıık alt boyutunda ise doçentlik lehine olduğu saptanmıştır. Vicdanlıık alt boyutunda doçentlik kadrosunun, kurumu övme ve bilgilendirme/katılım alt boyutunda ise öğretim görevlisi kadrosunun örgütsel vatandaşlık düzeyini arttırdığı ve diğer kadrolara göre örgütsel vatandaşlık düzeyinin daha yüksek olduğu söylenebilir. Doçentlik ve öğretim görevlisi kadrosunda yer alan akademisyen hemşirelerin görevi gereği, kurumdaki eğitim öğretim faaliyetlerine ve eğitimi etkileyebilecek önemli toplantılarda yer alması, örgütsel vatandaşık davranışlarını yaşayarak yerine getirebilme durumunu arttırmasından dolayı bu farkın ortaya çıktı̆ı düşünülmektedir. Dirican ve Erdil (2016)'in çalışmalarında öğretim görevlilerin öğretim üyelerine göre daha çok yardım etme örgütsel vatandaşlık davranışına sahip olduklarını bunu da öğretim üyelerinin iş yüklerinin fazla olması ve akademik hiyerarşi gibi nedenlerden ötürü geliştiğini belirtmektedir.

Çalışmaya katılan araştırma görevlilerinin örgütsel vatandaşlık düzeyi toplam ölçek puanının diğer akademik ünvanla- 
ra/kadrolara göre daha yüksek olduğu saptanmıştır (Tablo 2). Çalışma bulgularının aksine Dirican ve Erdil (2016)'in çalışmasında araştırma görevlilerin diğer akademik ünvanlara göre daha az örgütsel vatandaşılk davranışı sergilediği bulunmuş ve Ornstein, Cron ve Slocum Jr. (1989) göre kariyerlerinin başlangıç aşamasındaki bireylerin daha az katılımcı oldukları literatür bilgisiyle desteklenmiş olmasına rağmen akademik kariyerinin başında olan araştırma görevlilerinin daha yüksek puan ortalamasına sahip olmasının nedeni komisyon görevlerinde daha çok görev almaları ve bu komisyonların kurumu tanıma firsat vermesi ve bir kuruma ait olma isteği gibi nedenlerle örgütsel vatandaşlık davranışının geliştiği söylenebilir.

Çalışmaya katılan akademisyen hemşirelerin kadro durumları ile ÖVD puan ortalamaları arasında anlamlı bir fark bulunmuştur (Tablo 2). Bu farkın ölçek toplamı, vicdanlıık, kurumu övme, bilgilendirme/katlım ve yardım etme alt boyutlarında ve farkın 50/d tahsisli kadro durumu lehine olduğu saptanmıştır. Ölçek toplamında, vicdanlıık, kurumu övme ve yardım etme alt boyutunda 50/d tahsisli kadrosunun yüksek lisans, doktora tahsisli ve 33/a daimi kadrosuna göre örgütsel vatandaşlık düzeyinin daha yüksek olduğu söylenebilir. 50/d, 33/a, yüksek lisans ve doktora tahsisli kadrolarda görev alan akademisyenlerin araştrrma görevlisi olmaları nedeniyle kurumda birçok komisyon ve komitelerde görev almalarının kuruma olan aidiyetlerini arttrması ve bu nedenle örgütsel davranışlarını benimsemeleri diğer kadrolara göre daha yüksek bir örgütsel vatandaşlık düzeyine sahip olduklarını açıklayabilir. Bununla birlikte daimi ya da geçici kadroda bulunmanın örgütsel vatandaşlık düzeyini etkilediği söylenebilir. Çalışma bulgusunun aksine farkıı bir alanda yapılan bir çalışmada kadro durumunun örgütsel vatandaşlık davranışı üzerinde bir farklılık yaratmadığı belirlenmiştir (Yılmaz, 2009).

Çalışmaya katılan akademisyen hemşirelerin toplam çalışma yılları ile ÖVD puan ortalamaları karşılaştıııldığında (Tablo 2); hoşgörülük alt boyutunda farkın toplam çalışma yılı 21 yıl ve üzeri olanlar lehine olduğu saptanmıştır. Çalışma bulguları ile paralel olarak, Dirican ve Erdil (2016)'in akademisyen hemşireler üzerinde yaptıkları çalışmalarında, çalışma yılı fazla olanların örgütsel vatandaşlık davranış düzeylerinin daha yüksek olduğunu saptanmıştır. Baykal ve ark. (2011)'larının çaIışmasında ise akademisyen hemşirelerin tüm alt boyutlarda 5 yıl ve daha az mesleki deneyime sahip akademisyenlerin 6 yıl ve daha fazla mesleki deneyime sahip akademisyenlere göre daha yüksek alt boyut puan ortalamalarına sahip oldukları belirlenmiş ancak gruplar arasında anlamlı bir fark bulunmamıştır.

Aktay (2008), Karakuş (2008) ve Özer (2009) çalışmalarında meslekte çalışma süresinin artması ile örgütsel vatandaşık düzeyini arttırdığını saptamışlardır. Arı ve ark. (2017)'ları çalışanların hizmet süresi arttıkça örgüte yatıııın ve örgütten elde edilecek kazançların arttğı, bu yüzden ayrılma durumunda oluşabilecek kayıpları yaşamamak adına örgüte bağlıı̆ın arttğını vurgulamaktadır. Bu çalışmalar yapılan bu araştırma bulgularını destekler niteliktedir. Toplam çalışma yıı 21 yıl ve üzeri olanların daha çok öğretim üyesi olmaları ve kurum içindeki tüm faaliyetlerde yer almaları örgütün davranışlarını sergilemelerini ve bu örgütsel vatandaşlık davranışlarını uygulamalı olarak yerine getirebilmelerini sağladığı için ÖVD düzeylerinin diğerlerine göre daha yüksek olduğu düşünülmektedir. Ayrıca, çalışma da 21 yıl ve üzeri olanların daha hoşgörülü davranış sergiledikleri saptanmıştır. Bunun yıllar içerisinde tecrübeleriyle öfkelerini yapıcı bir şekilde yönetmeyi öğrendikleri ve daha hoşgörülü olmalarını sağladığı belirtilmektedir (Thomas, 2002).

\section{Sonuçlar}

Türkiye'de hemşirelik eğitimi veren kurumlarda görev yapan akademisyen hemşirelerin örgütsel vatandaşlık düzeylerini belirlemeye yönelik yapılan araştırma sonucunda; Örgütsel Vatandaşlık Düzeyinin orta düzeyde olduğu saptanmıştır. Eğitim durumu, akademik kadro, toplam çalışma yılı örgütsel vatandaşlık davranışını etkileyen önemli değişkenler olarak saptanmıştır. Akademisyen hemşirelerin ÖVD ölçeğine göre hoşgörülü oldukları, iş tanımlarında yer almayan ve yerine getirilmesi bireylerin kararına bırakılmış olan örgütsel vatandaşlık davranışını sergileme eğiliminde oldukları saptanmıştır. Doktoralı akademisyen hemşire ve araştırma görevlisi olmanın örgütsel vatandaşlık davranışlarını etkilediği bulunmuştur.

\section{6. Öneriler}

Bu çalışma sonuçları doğrultusunda, akademisyen hemşire yöneticilerin, kurumlarındaki hemşire akademisyenlerin örgütsel vatandaşlık davranışlarını sergileyen hemşire akademisyenleri destekleyip ödüllendirmesi, hemşire akademisyenler arasında olumlu etkileşimler sağlayarak birbirleri ile yardımlaşmasını sağlayıcı girişimlerde bulunmaları, kurumda grup çalışmalarının özendirilmesi ve farklı grupların birlikte çalışmaları sağlanarak ben kavramı yerine biz kavramının ön plana çıkarılması ve çalışanlarının fazladan rol davranışlarının arttırılabilmesi için örgütsel adalet algısının sağlanması önerilmektedir.

\section{Kaynakça}

Acquaah, M. (2004). Human Factor Theory, Organizational Citizenship Behaviors and Human Resources Management Practices: An Integration of Theoretical Constructs and Suggestions for Measuring the Human Factor. Review of Human Factor Studies Special Edition, 10(1), 118-151.

Aktan C. C. (2009). Yüksek Öğretimde Değişim: Global Trendler Ve Yeni Paradigmalar. Organizasyon Ve Yönetim Bilimleri Dergisi,1(2), 39-97 
Alim, A.M.M., \& El-Sayed, R. (2017). Organizational Attributes And Its Relation To Organizational Citizenship Behavior Among Academic Nursing Staff. Egyptian Nursing Journal, 14, 25-30.

Aktay, A. (2008). Yönetici ve Öğretmenlerin Değer Tercihleri lle Örgütsel Vatandaşlık Davranışları Arasındaki Ilişkinin İncelenmesi. Yayınlanmamış Yüksek Lisans Tezi. İstanbul: Yeditepe Üniversitesi Sosyal Bilimler Enstitüsü.

Altuntaş, S., \& Baykal, Ü. (2010). Örgütsel Vatandaşlık Düzeyi Ölçeğinin Hemşirelikte Geçerlik Güvenirliği. Anadolu Hemşirelik ve Sağlık Bilimleri Dergisi, 13(3), 7-16.

Arı, M., Gülova, A.A., \& Köse, S. (2017). Örgütsel Adalet Algısı İle Örgütsel Bağlılık Davranışının iliş̧kisi: Bir Sağılı Kuruluşunda Araştırma. Dokuz Eylül Üniversitesi Hemşirelik Fakültesi Elektronik Dergisi, 10(1): 43-51.

Avcı, A. (2015). Örgütsel Vatandaşlık Davranışları: Kavramsal Gelişimi ve Eğitim Örgütleri Açısından Etkileri. Hasan Ali Yücel Eğitim Fakültesi Dergisi, 12-2 (24), 11-26.

Baykal, Ü., Altuntaş, S., Öztürk, H., Sökmen, S., İntepeler, S.Ş., \& Kantek, F. (2011). Akademisyen Hemşirelerin Örgütsel Vatandaşlık Davranışlarını ve Etkileyen Faktörler. Hemşirelikte Eğitim ve Araştırma Dergisi, 8 (3), 52-58.

Bolat, O. I., Bolat, T., Aytem, O., \& Seymen, Z. (2009). Güçlendirici Lider Davranışları ve Örgütsel Vatandaşlık Davranışı Arasındaki Ilişkinin Sosyal Mübadele Kuramından Hareketle İncelenmesi. Balıkesir Üniversitesi Sosyal Bilimler Enstitüsü Dergisi, 12 (21), $215-239$.

Çalık, T., Özbay, Y., Erkan, S., Kurt, T., \& Kandemir, M. (2009).illköğretim Okullarında Okul íklimi, Zorbalık ve Prososyal Davranışlar Arasındaki İlişkilerin İncelenmesi. Kuram ve Uygulamada Eğitim Yönetimi, 15(60), 555-576.

Dirican, A., \& Erdil, O. (2016). An Exploration of Academic Staff's Organizational Citizenship Behavior and Counterproductive Work Behavior in Relation to Demographic Characteristics. Procedia - Social and Behavioral Sciences, 235, 351- 360.

Doğrul, M. A. (2013). Örgütsel Bağlilik Ve Örgütsel Vatandaşlık Davranışı Arasındaki iliş̧ki: Afyon Meslek Yüksek Okulu’nda Çalışanlar Üzerinde Bir Araştırma. Afyon Kocatepe Üniversitesi, Sosyal Bilimler Enstitüsü İşletme Anabilim Dalı, Yayınlanmamış Yüksek Lisans Tezi, Afyon.

Feather, N.T., \& Rauter, A.K. (2004). Organizational Citizenship Behaviours In Relation To Job Status, Job Insecurity, Organizational Commitment And Identification, Job Satisfaction And Work Values. Journal of Occupational and Organizational Psychology, $77,81-94$.

İşsever, H., Söyük, S., \& Şengün, H. (2016). Kamu Hastanelerinde Çalışan Hemşirelerde Örgütsel Vatandaşlık Davranışı. NobelMed, 12 (3), 29-38.

Karakuş, M. (2008). Illköğretim Okul Yöneticilerinin Ve Öğretmenlerin Duygusal Zeka Yeterli-Liklerinin, Öğretmenlerin Duygusal Adanmışlık, Örgütsel Vatandaşıık Ve Iş Doyumu Düzeylerine Etkisi. Yayınlanmamış Doktora Tezi. Elazığ: Fırat Üniversitesi Sosyal Bilimler Enstitüsü.

McDonald, P. R. (1993). Individual-Organizational Value Congruence: Operationalization and Consequents. Unpublished Doctoral Dissertation. London, Ontario: The University of Western Ontario.

Ornstein, S., Cron, W. L., \& Slocum, J. W. J. (1989). Life Stage Versus Career Stage: A Comparative Test Of The Theories Of Levinson And Super. Journal of Organizational Behavior, 10, 117-133.

Öz, M., \& Özyürek, P. (2018). Cerrahi Hemşirelerinin Profesyonel Değer Algıları ve Örgütsel Vatandaşlık Davranışları Arasındaki ilişkinin Belirlenmesi. Journal of Health and Nursing Management; 5(2), 113-122.

Özer, S. (2009). Eğitim Örgütlerinde Lider Davranış Biçimleri lle Örgütsel Vatandaşlık Davranışı Arasındaki llişki (Nevşehir ili Örneği). Yayınlanmamış Yüksek Lisans Tezi. Kayseri: Erciyes Üniversitesi Sosyal Bilimler Enstitüsü.

Özkütük, N., Orgun, F., Sezer, H., \& Çakan Güneysu, A. (2012). Hastanede Çalışan Hemşirelerin Örgütsel Vatandaşlık Düzeylerinin İncelenmesi, Ege Üniversitesi Hemşirelik Fakültesi Dergisi, 28 (3), 1-12.

Öztürk, E. Y., \& Özata, M. (2013). Hemşirelerde Örgütsel Vatandaşlik Davranışı ile Tıbbi Hataya Eğilim Arasindaki llişkinin Araştırılması, Süleyman Demirel Üniversitesi İktisadi ve İdari Bilimler Fakültesi Dergisi, 18(3), 365-381.

Pirecioğlu, F. M. (2010). Örgütsel Vatandaşlık Davranışı Ve Bir Üniversite Hastanesinde Çalışan Hemşirelere Yönelik bir Araştırma. Beykent Üniversitesi, Sosyal Bilimler Enstitüsü İşletme Yönetimi Anabilim Dalı Hastane ve Sağlık Kurumları Yönetimi Bilim dalı, yayınlanmamış Yüksek Lisans Tezi, İstanbul.

Sezgin, F. (2005). Örgütsel Vatandaşlık Davranışları: Kavramsal Bir Çözümleme ve Okul Açısından Bazı Çıkarımlar GÜ, Gazi Eğitim Fakültesi Dergisi, 25(1), 317-339

Titrek, O., Bayrakçı, M., \& Zafer, D. (2009). Öğretmenlerinin Örgütsel Vatandaşlık Davranışlarına ilişkin Görüşleri. Uluslararası Hakemli Sosyal Bilimler E-Dergisi, 17, 1-12.

Thomas, S. P. (2002). Age Differences in Anger Frequency, Intensity, and Expression. Journal of the American Psychiatric Nurses Association, 8(2), $44-50$.

Pohlman, R. A., \& Gardiner, G. S. (2000). Value Driven Management. How to Create and Maximize Value Over Time for Organizational Success. New York: AMACOM Press.

Schnake, M. E., \& Dumler, M. P. (2003). Levels of Measurement and Analysis Issues in Organizational Citizenship Behaviour Research. Journal of Occupational and Organizational Psychology, (76), 283-301.

Smith, C. A., Organ, D. W., \& Near, J. P. (1983). Organizational citizenship behavior: Its' nature and antecedents. Journal of Applied Psychology, 68, 653-663.

Somech, A. , \& Drach-Zahavy, A. (2004). Exploring Organizational Citizenship Behaviour from an Organizational Perspective: The Relationship Between Organizational Learning and Organizational Citizenship Behaviour. Journal of Occupational and Organizational Psychology, (77), $281-298$.

Wagner, S. L., \& Rush, M. C. (2000). Altruistic Organizational Citizenship Behavior: Context, Disposition, and Age. The Journal of Social Psychology, 140(3), 379-391.

Yıldıım, E. (2009). Sınıf Öğretmenlerinin İstihdam Biçimlerine Göre Örgütsel Vatandaşlık Davranışı Algıları. Sakarya Üniversitesi, Sosyal Bilimler Enstitüsü, Adapazarı

Yıldıım, S., \& Çam O. (2011). Akademisyen Hemşirelerin Çalışma Yaşamına Yönelik Tutumlarının İncelenmesi. Psikiyatri Hemşireliği Dergisi, 2(1), 1-8.

| Kastamonu Eğitim Dergisi, 27(5), 2019| 